\title{
제 3차 혁신적 개발재원 리딩그룹 총회
}

I. 개요

- 일 시 : 2007년 9월 3일(월) 4일(화)

- 장 소 : 소공동 롯데호텔

- 주요 일정

- 외교통상부장관 환영사 및 유엔사무총장 축하영상메세지

- 전체회의(Plenary Session) 및 라운드테이블 토의 진행

- 차기 의장국 선출

- 참 석 : 35 개국 정부대표 70 여명을 비롯, $\mathrm{UN}$ 등 국제기구와 $\mathrm{NGO}$ 관계자 등 총 120 여명

II. 주요 결과

- 항공권연대기여금의 도입과 국제의약품구매 기구(UNITAID)를 통한 기여금운용 등 혁신
적 개발재원 분야에서 국제사회가 이룩한 성 과 확인

- 국제금융백신기구(IFFIm), 선시장공약 (AMCs) 등 최근에 출범한 혁신적 개발재원 메커니즘의 의의와 개발재원 확대에 미치는 효과 확인

- '개발을 위한 외환거래세', ‘조세피난과 자본 유출경감 ', 이민자 송금 ‘등 새로운 재원도입 가능성 논의

- 2008년 하반기에 예정된 ' 몬테레이 컨센서스 이행점검을 위한 도하 개발재원회의 '와 연계 하여 향후 리딩그룹의 발전방안 논의

- 세네갈을 차기 의장국으로 선출하고 제 4차 총회를 2008.3월 다카에서 개최하기로 합의 


\section{반기문 UN사무총장 축하영상메세지}

Foreign Minister Song Min-soon,

Distinguished participants and ladies and gentlemen,

I am happy to address this 3rd plenary meeting of the Leading Group on Solidarity Levies to Fund Development even if I do so long distance.

This meeting is held in my native country. During my tenure as Minister of Foreign Affairs and Trade, the Republic of Korea decided to join the leading group. Today as the secretary general of the United Nations I continue to strongly support the exploration of innovative mechanisms for financing for development.

Since the establishment of the Leading Group in 2006, several creative projects in the area of financing for development have already been launched, the air-ticket solidarity levy, the international finance facility for immunization, the advanced market committment pilot program. The meeting provides a unique opportunity to take start of the progress made to date in these and other initiatives. It also allows you to exchange experiences and lessons learned as we move forward in achieving the internationally agreed development goals.

As you know this year marks the mid-point in our global pursuit to achieve the Millennium Development Goals by 2015. Yet the funding gap we are facing reminds us all of the crucial needs for additional flows of development finance. Closing this gap is essential if we are to alleviate extreme poverty, fight diseases, and achieve the other development targets.

It is vital that the momentum be maintained and that new funding initiatives be encouraged. This is all the more important as we prepare for the follow-up international conference on financing for development to be held in Doha in 2008.

The United Nations system has an important role to play in the area of innovative financing for development. The UN is a catalyst for new ideas, it is a forum for 
consensus building and it is an engine for implementation. In that spirit I wish to reiterate the firm support of the United Nations to the Leading Group. I thank every one of you for your committment and wish you a most productive meeting.

Thank you.

\section{송민순 외교통상부 장관 환 영 사}

Excellencies, Distinguished Guests, Ladies and Gentlemen,

On behalf of the Government of the Republic of Korea, I would like to start by extending a warm welcome to all of you to the Third Plenary Meeting of the Leading Group on Solidarity Levies to Fund Development. It is indeed a great pleasure to welcome such an impressive array of participants, including representatives Member States, international organizations and NGOs.
I look forward to this meeting building upon the valuable work done at the previous Plenary Meetings held in Brasilia and Oslo. I am confident that this Meeting will also serve as a valuable occasion to review the achievements of the discussions so far on innovative financing for development. I hope that we can also gain a renewed sense of their importance in our common efforts to eradicate poverty and combat diseases, a noble aim that unites us. Furthermore, this Meeting will undoubtedly help rally the support of the international community on the issue of innovative financing for development.

Let me touch on poverty and terrorism with a few words. One of the threatening challenges that are ubiquitous todayis terrorism. Nobody is safe from the threat. While introducing political security and safety measures to prevent and subdue coward act of terrorism including kidnappingand killing innocent people, what we have to do is focus on the root causes of these persistent evil. I think that the answer lies in the international concert to eradicate poverty and encourage sustainable development. 
Distinguished Guests,

The international community unites in recognition that the eradication of poverty and sustainable development is keyin our efforts to achieve peace, development and human rights. Namelyit is an imperative element in our pursuit of the common ideals of humanity. More than at any other time in the history of humankind, the present generation has given profound thought to this issue and has been striving to find the best way to rise to the challenge.

Securing the resources for developmentis, more than any other factor, the starting point for overcoming poverty and underdevelopment. In this regard, through the Monterrey Consensus in 2002 the international community came to an agreement to substantially increase Official Development Assistance. Nevertheless, both the quantity and the quality of resources for development are still issues that need to be addressed. It is this recognition that has yielded the idea of innovative financing for development.

Despite its short history, the idea of innovative financing for development is emerging as a major issue on the agenda of theinternational community. In particular, through the Declaration on Innovative Sources of Financing for Development in 2005, the international community has confirmed that innovative financing for development is indeed an essential tool for the eradication of poverty and has made clear its commitment to work further to this end.

Moreover, I am very pleased to note the visible and valuable achievements reached by such new mechanisms including the airticket solidarity contribution, International Finance Facility for Immunization (IFFIm) and Advanced Market Commitments (AMCs).

Ladies and Gentlemen,

As an emerging donor, Korea is now making utmost efforts to secure more and better aid. In addition, the Government of Korea has also actively taken part in the discussions on innovative financing for development. In this regard, Korea assumed the Presidency of the Leading Group in March 2007, and is also a member of the Executive Board of UNITAID, 
representing the Asian countries.

In particular, the Korean government has enacted alaw to formally introduce the international air-ticket solidarity contribution. This measure, which will take effect from September 30, will impose a charge of one thousand Korean won, equivalent to one dollar, on each departing international air-ticket to be used as resources for development. The Korean government plans to make use of the resources in particular to combat poverty and diseases mainly in the African region.

The Leading Group on Solidarity Levies to Fund Development has played a key role in making great progress in the discussions on new mechanisms of financing. This Meeting of the Leading Group has now emerged as the most significant forum in the field of innovative financing for development with participants from 53 countries in Europe, Africa, South America and Asia, and relevant international organizations and civil society.

This Third Plenary Meeting holds special meaning in that it provides an invaluable opportunity to examine the achievements made so far. I look forward to us all reflecting on how far we have come and so pooling our wisdom to set the future direction for our discussions.

Excellencies, Distinguished Guests, Ladies and Gentlemen,

Absolute poverty is not only a humanitarian calamity but a real threat to peace, human rights and the dignity of humankind. I believe that innovative financing for development is emerging as a powerful tool for the international community in their fight against poverty.

Once again, I wish to extend a heartfelt welcome to you all. In Korea, Autumn starts with September. I hope that in this season of harvest you will take home with you many fruitful results from this meeting.

Thank you. 


\section{제 3차 혁신적 개발재원 리딩그룹 총회 \\ 발표자료 : Major Achievements and Reflections on Innovative Financing for Development}

\section{GENERAL REMARKS ON} MAJOR ACHIEVEMENTS

by Mari Skåre / Senior Adviser, Norwegian Ministry of Foreign Affairs

Thank you Mr. Chairman,

The Leading Group on Solidarity Levies to Fund Development is now in its second year. It is still a very young initiative, but the issue at hand is not new how to meet the challenges of financing development. The Leading Group's advantage compared to many other international fora is that it provides an arena for bringing new ideas to the table and to have frank and focused discussions on selected topics. As was highlighted by the chair of the conference in Oslo in February the Group's mission lies in moving issues forward and increase their prominence on political agendas.

Some of the ongoing processes, and in particularly the innovative financing mechanisms related to the health sector, have matured and are now becoming operative, and I would add - successfully so. The International Finance Facility for Immunization (IFFIm) raises funds in the international capital markets and has during its first year of operation mobilised more than 800 million dollars to GAVI funded vaccine programme and activities. This equals the 
sum disbursed by ordinary GAVI allocations since the start of GAVI in 2000.

Even more directly a spin-off of this group is the International Drug Purchase facility UNITAID, that was launched in September 2006, during the General Assembly of the United Nations. Essentially financed by solidarity levies on airline tickets, it benefits greatly from the prospects of stable and sustainable resources in leveraging reduced price and access to life saving drugs for the poorest countries. France has here been able to demonstrate to its citizens the direct link between small, individual solidarity contributions and the rapid achievement of remarkable results.

The UNITAID initiative has in may ways overcome the divides between "donors" and "recipients", with a high buy-in from countries on all continents. When the stakeholders assemble, the dialogue is deeper, more equal and more result oriented than in many of the more traditional intergovernmental fora. In addition, civil society engage at all levels of governance and bring their impatience, creativity and challenges, contributing greatly to taking the agenda forward. While still in its early stages, UNITAID is so far possibly the most convincing product of solidarity levies in terms of making the case to the public.

One of the panel debates in Oslo in February was on a pilot Advance Market Commitments (AMC)for a pneumoccal vaccine. The innovative aspect of AMC is clearly that of providing industry with an incentive to develop a vaccine without funding it and that most likely would not have been prioritised by industry. A prerequisite is that the vaccines to be approved have to betargeted specifically to developing countries. Norway is currentlychairing the donor committee setting up the initiative which is scheduled to be operative by the end of this year.

The international debate on migrants' remittances has also been moving forward and was discussed at the Global Forum on Migration and Development in Brussels in July this year. Many countries are now focussing on the issues on remittances on both an international and a national level, and,for instance in Norway, we are working on improving conditions for migrants to remit money to their countries of origin and have 
initiated a pilot project to direct funding to sustainable development initiatives.

At the Oslo conference in February there were two thematic issues for which the call for active follow-up was particularly vocal; this was the issue of currency transaction levy andthe issue of tax havens and their role in facilitating capital flight from developing countries. The idea of establishing task forces for the two issues under the Leading Group was put forward.

I am pleased to announce that Norway is willing to take a lead in a task force addressing the role of the so called tax havens' and capital flight from developing countries. In consultation with interested partners we will draw up objectives, work methods and a time frame for this work. France, Spain and Chile have already indicated their interest, but needless to say, we hope more countries will join.

One objective should be to get more data on the table. We need to have better knowledge and understanding of the nature of the financial structuresand what role they play in money laundering and hiding stolen assets.
The cross-border flow of the proceeds from criminal activity, corruption, and tax evasion is estimated to be between 1 and 1.6 trillion dollars every year. A large chunk of this comes from developing countries. We need to know more about these flows and the mechanisms and financial structures that support them. We are particularly interested in understanding the role of tax havens in hiding stolen assets deriving from resource extraction and the role of these structures in what is referred to as 'the paradox of plenty'. We are of course open for suggestions from partners on other focus areas.

Partners in this Group have already provided valuable information and analysis. We are currently in dialogue with the World Bank on the need for developing a better knowledge base on the flows of illicit capital and the mechanisms and structures set up to hide stolen assents. The Stolen Asset Recovery Initiative (STAR) is being launched jointly by the UN Office on Drugs and Crime and the World Bank Group 17 September. We welcome this initiative. Prevention of theft and recovery of stolen assets from developing countries is a daunting challenge and focus should be on retention of capital - as well as 
on recovery.

The review conference on Financing for Development will take place in Doha, tentatively in December 2008. We wish to bring the issue of capital flight, and in particular illicit flows of capital out of developing countries, higher on the international agenda and discussed also in the United Nations.

In the Monterrey Consensus it is stated that a critical challenge is to ensure the necessary internal conditions for mobilizing domestic savings, and that an enabling domestic environment is vital also for reducing capital flight. Another side of the equation are the financial centres - often located in developed countries - setup to hide stolen assets. These mechanisms need to be better understood and we hope that a task force under the Leading Group can contribute to the Finance for Development Process by raising awareness and identifying key areas for action

Our intention is to invite the task force to Oslo towards the end of this year and report back to the next plenary meeting of the Leading Group. We envisage another $2 \sim 3$ meetings leading up to the conference in Doha and invite all interested partners to participate in this process.

Mr. Chairman,

As I said initially; the mission of the Leading Group lies in bringing issues forward. The work of this Group has already produced some good results. In the run up to the Doha conference, partners should consider these results and the relevance of bringing these discussions into the broader financing for development discussion in the UN. Many of the issues we are discussing - currency transaction levies, tax havens and capital flight, or remittances are complex issues and we probably will need to have a long-term perspective on this work. We also need to collaborate closely with other partners outside this Group.

I am a new participant in this group and allow me on a personal note to say how pleasedI am to be here. I am very much looking forward to cooperate with this fine group of knowledgeable people and learn from you how we, in the spirit of solidarity, can work together to fight hunger and poverty and ensure sustainable development. 
I wish to thank the Government of the Republic of Korea for hosting this meeting, I am confident that this Group will continue to take the lead on designing innovative financing mechanisms. We will do this by engaging the best knowledge available, by including nongovernmental organizations, research institutions and other participants from civil society and engaging in frank and open discussions on the way forward.

Reflections on Innovative Financing for Development

by Alexander Trepelkov / Deputy Director, Financing for Development Office Department of Economic and Social Affairs United Nations

Distiguished Participants,

Ladies and Gentlemen,

It is my great honour and pleasure to address the Third Plenary Meeting of the Leading Group on Solidarity Levies to Fund Development, hosted by its incumbent
Presidency, the Republic of Korea, in the capital city of Seoul. This meeting provides a unique forum for participating member and observer countries, international institutions and civil society to exchange views on the achievements and challenges in the area of innovative financing for development. On behalf of the United Nations Department of Economic and Social Affairs, I wish to extend our warm greetings and appreciation to the organizers and participants of this important international event.

\section{The setting}

It is generally recognized that official development assistance (ODA) continues to play a crucial role in financing the internationally agreed development goals, including the Millennium Development Goals (MDGs). As a result of the 2002 Monterrey Consensus on Financing for Development, the declining trend of ODA was reversed. ODA rose from $\$ 52.4$ billion in 2001 to $\$ 106.5$ billion in 2005, or from 0.21 per cent to 0.33 per cent of the gross national income (GNI) of developed countries. However, a large part of the increase was due to debt relief, emergency aid and technical cooperation. 
Hence, with the reduction of debt relief in 2006, ODA dipped to 0.30 per cent of GNI.

Despite the recent advances and new commitments, the current and projected levels of ODA for the period $2006 \sim 2010$ still fall far short of targets. It has been estimated that at least $\$ 150$ billion a year would be needed to reach the MDGs by 2015 . The collective ratio of ODA to GNI is projected at 0.36 per cent by 2010, well below the historical peak of 0.5 per cent in the 1960s and the United Nations target of 0.7 per cent. Indeed, the funding gap at the mid-point of the global pursuit to achieve the MDGs by 2015 confirms the need for additional flows of development finance, including through new and innovative mechanisms. Looking beyond 2015, additional resources would still be required to finance longer term development objectives and a range of "global public goods".

\section{The proposals}

Over the years, there have been a large number of proposals for innovative financing mechanisms. With a few exceptions of recent vintage, most of the proposals are not entirely new. Currently, international attention is being focused on a few key proposals. They fall into three major categories grouped by source of funding: (1) alternative means of mobilizing public resources (or financial engineering); (2) global taxation; and (3) private contributions.

The overarching objective of all proposed mechanisms is to mobilize new and additional resources for development, on a stable and predictable basis. In evaluating them, main criteria include: (1) their revenue potential; (2) speed of availability or implementation; (3) political feasibility; and (4) level of participation required for success.

\section{Alternative means of mobilizing public resources}

Among alternative means of mobilizing public resources, the United Kingdom's proposal for an International Finance Facility (IFF) seems to show the greatest potential.This proposal involves borrowing against future ODA commitments. Its particular feature is that it enables front-loading aid flows through a bond mechanism guaranteed by participating governments, thus allowing aid commitments to be used before they are budgeted. In its 
original design, it would increase ODA disbursements up to \$50billion in 2010-2015 but could reduce them thereafter down to zero by 2020 , partly as a result of repayment of the bonds used to accelerate aid disbursements. It therefore needs to be accompanied by refinancing mechanisms that will ensure that adequate financial flows will be available to meet development needs beyond 2015. To be effective, IFF requires sufficient donor countries to sign up and continue to make commitments. A pilot project for a small-scale facility, International Finance Facility for Immunization(IFFIm), of $\$ 4$ billion over 10 years was launched by a public-private partnership, Global Alliance for Vaccines and Immunization (GAVI), with the support of seven donor countries, to test this mechanism experimentally.

Another proposal of this group, Special Drawing Rights (SDRs) for Development Purposes, in particular the MDGs, was put forward in 2002 by George Soros. The proposal would involve the allocation by developed countries of SDRs to a dedicated trust fund, either by gift or through a redistribution of quotas, which would require amending the IMF Articles of Agreement. It has the potential of generating some $\$ 25$ billion, depending on periodicity of allocations to developing countries. Beneficiaries would receive long-term loans at low interest rates. The 1997 amendment for a special and unique allocation to double cumulated allocations to SDR 43 billion ( $\$ 65$ billion) has yet to be ratified by 100 IMF members with 85 per cent of voting power. Several developed countries have opposedthe idea on the grounds that it would be inflationary (an argument which can be overcome if the amount issued does not exceed the demand for international reserves) and that it confuses the role for which SDRs were created. Another obstacle is lost interest income to SDR providers.

\section{Global taxation}

Proposals for global taxation in support of development have a long history and are often criticized on grounds of feasibility. Thus, these taxes need to be designed as financing tools that are nationally applied and internationally coordinated and that entail limited management costs. While universal participation is not indispensable, it would serve the interest of development, as more 
resources would be raised. In the short term, however, progress can be made with the participation of a small group of countries.

One type of tax that has been commonly suggested is aCurrency Transaction Development Levy (CTDL). Its estimated revenues would range from $\$ 30.6$ billion to $\$ 35.4$ billion per annum if it was equivalent to two basis points of market currency transactions, and from $\$ 16.8$ billion to $\$ 19.2$ billion if it was equivalent to one basis point. It is also seen as playing a dual role ("double dividend") in that it should reduce volatility in the international financial system and provide substantial financial resources for development. However attractive the tax might be in terms of revenue potential, its implementation is constrained by several obstacles. The tax base will have to be defined so as to exclude transactions by market-makers and special treatment for derivatives to avoid double taxation. It will also have to be protected from erosion, for even if all major financial centers participate, there is a risk that smaller centers will attract an increasing volume of activity from those wishing to evade the tax. Besides, strong opposition by major stakeholders (who account for the majority of the transactions to be taxed) must be overcome.

Another type, Global environmental taxes, are also seen as yielding a "double dividend" in that they should benefit the environment while also raising significant resources for development. A front-runner among several proposals is the carbon tax which would be applied to carbon emissions. On the basis of a figureof $\$ 21$ per ton (5 cents per gallon) of gasoline, revenues would reach $\$ 130$ billion per annum and $\$ 61$ billion per annum if the tax was restricted to high-income countries. However, several challenges arise: the need to consider "free-riding" risks by countries not applying the tax; the need to coordinate the tax with the current practice of negotiable emission permits established by the Kyoto Protocol to the UN Framework Convention on Climate Change; and redistributive effects that might require and international agreement on compensation.

Most recently, Solidarity Levy on Airline Tickets, proposed by France, has come to the centre of international attention. It is widely recognized that taxing air transport makes economic sense. The level of taxation onair transport is lower than on other means of 
transport, since aviation fuel is tax-exempt. Aircraft engine emissions play a major role in global warming; however, they are not covered by the Kyoto Protocol to the UN Framework Convention on Climate Change. Several options seem to be technically feasible. Taxing aviation fuel would have a positive environmental effect. A tax on airline tickets could easily be implemented and would present no legal obstacles. A positive public perception could be achieved by allocating such contribution to a fund dedicated to a precise development objective. In view of the small size of this levy, it would produce a minimal impact on airline activity. A 5 per cent rate applied to first-class and business-class tickets would yield $\$ 8$ billion per annum, while a $\$ 1$ contribution on each ticket issued would yield about $\$ 3$ billion per annum. Another alternative would involve the indirect taxation of air flight corridors: revenues could reach $\$ 10$ billion per annum. An indirect tax on passenger transportation could reach $\$ 20$ billion per annum.

Arms trade taxcould yield between $\$ 2.5$ billion and $\$ 8$ billion per annum. It is also advocated as having a "double dividend". However, if its full potential is to be realized, it is important to ensure that the tax is passed through from the seller to the buyer so that the cost of acquiring arms is effectively increased. Also, if the mechanism is to be efficient, it would be crucial to form a large coalition, including all major arms producers and exporters.

\section{Private contributions}

Among various means of mobilizing private resources for development, Migrants' remittances have recently attracted special attention. Remittances are neither new nor innovative, but they have boomed in recent years and are now larger than ODA flows. Various measures are already being taken by various governments and private sector agencies to facilitate such flows. Remittances remain within the private sector and are largely used for consumption by the migrants family. Thus, their contribution to societal development goals is unclear, but some innovative ideas are being designed (e.g., co-financing by governments of funds sent by migrants for the development of their community, incentives to attract migrants' savings to their country of origin, etc.).

Incentives to private donationsfrom industrial 
countries to programmes for the poor in developing countries may be provided in various ways. Donations can be encouraged through tax deductions, credit card payments or utility bills. Mechanisms linked to voluntary contributions benefit from but do not require international coordination.

Other proposals in this category include Global lottery and Global development bond.

\section{The role of the United Nations system}

The United Nations has been at the forefront of international efforts to explore innovative sources and mechanisms of financing for development. Basically, the role of the United Nations system is three-fold. First, the United Nations Secretariat acts as a catalyst for policy analysis and new ideas. Second, the United Nations intergovernmental machinery provides a forum for consensusbuilding. Third, United Nations agencies serve as agent for implementation.

\section{Acting as a catalyst for policy analysis}

In the area of policy analysis, UN-DESA commissioned the World Institute for
Development Economics Research of the United Nations University (UNU-WIDER) to examine existing proposals, focusing on their design and policy implications. The project resulted in a comprehensive study, entitled "New Sources of Development Finance", which was published in 2004. The policyfocused summary of the study was submitted to the UN General Assembly. In addition, an analytical review of innovative sources of finance was included in the UN-DESA flagship publication, World Economic and Social Survey 2005: Financing for Development.

\section{Providing a forum for consensus building}

Over the recent years, the issue of innovative finance, once considered politically contentious andtechnically arguable, has been mainstreamed into United Nations development agenda. It now features prominently in the intergovernmental deliberations on economic and social matters, both within and outside the United Nations system.

In September 2004, the United Nations hosted a Meeting of World Leaders for Action 
against Hunger and Poverty, which launched multilateral discussions on innovative financing mechanisms at the highest level, led by the leaders of Brazil, France, Chile and Spain. The Meetingconsidered a report by the Technical Group on Innovative Financing Mechanisms, which provided a menu of viable options for implementation in the short, medium and long terms. As a result, more than 110 countries subscribed to the New York Declaration calling for special attention to innovative financing mechanisms - public and private, compulsory and voluntary, of universal and limited membership - to provide additional and stable funding for development.

In April 2005, the joint Development Committee ofthe World Bank and IMF reviewed proposals to complement increased aid flows with innovative mechanisms, such as IFF, global taxes and voluntary contributions, and welcomed further work on innovative sources of development financing. Accordingly, the issue of innovative sources of finance featured prominently on the agendas of the 2005 and 2007 spring highlevel meetings of ECOSOC with the Bretton Woods institutions, WTO and UNCTAD.
At the September 2005 World Summit, the world leaders recognized the value of developing innovative sources of financing and took note with interest of the international efforts, contributions and discussions in that regard. Moreover, 79 countries endorsed the Declaration on innovative sources of financing for development, initiated by Algeria, Brazil, Chile, France, Germany and Spain.

At the end of last year, the UN General Assembly decided that the Follow-up International Conference on Financing for Development to Review the Implementation of the Monterrey Consensus will be held in Doha, Qatar in the second half of 2008. It was agreed that the Review Conference should assess progress made, reaffirm goals and commitments, share best practices and lessons learned. It should also identify obstacles and constraints encountered and actions and initiatives to overcome them, as well new challenges and emerging issues. The issue of innovative sources of development finance is precisely the case in point.

The upcoming third High-level Dialogue on Financing for Development (New York, 22-23 
October 2007) is expected to serve as an important building block for the substantive preparation of the Doha Review Conference.

\section{Serving as an agent for implementation}

Since the establishment of the Leading Group in March 2006, several innovativeprojects have been launched and some have already reached implementation phase. To date, 28 countries have committed themselves to introducing the Air Ticket Solidarity Levy and have agreed to use the proceeds to scale up access to treatments against HIV/AIDS, TB and malaria, through the International Drug Purchase Facility, UNITAID. The International Finance Facility for Immunization, launched by seven countries in November 2006, has successfully priced its bonds on the capital market and is expected tochannel predictable funding flows through the Global Alliance for Vaccines and Immunization (GAVI). Similarly, the Advance Market Commitments pilot programme, launched by five countries and the Gates Foundation in February 2007, combines market-based financing tools with public intervention to provide long-term funding for the development of vaccines.
The United Nations is committed to the active engagement of UN agencies and related organizations in innovative financing mechanisms, as already demonstrated, for example by UNAIDS, UNICEF and WHO in UNITAID, and by UNICEF, WHO and the World Bank in GAVI.

\section{Conclusions and the way ahead}

While the scale of funds raised through innovative mechanisms has been rather small, their major achievement has been to seek new and additional resources for development, on a more stable and predictable basis. It is important that the momentum of these efforts be maintained and that new initiatives be encouraged, especially in the context of the preparation of the FollowupInternational Conference on Financing for Development, to be held in Doha, Qatar in the second half of 2008. Overall, the key challenge is to keep building consensus around pilot projects and to enhance international cooperation in this area.

In order to mobilize wider support for new funding mechanisms, priority should be given to realistic projects with tangible results. 
Such projects may be further prioritized by the volume of financial flows they can leverage and the impact on development they can produce. It is essential that an appropriate balance between international coordination and national implementation of projects be observed. Civil society and the private sector should more actively engage, through public-private partnerships, in designing innovative projects and monitoring the use of resources. As much as possible, the funds collected should be pooled and disbursed through existing international institutions with proven track records in achieving development results.

In concluding, I wish to commend the work of the Leading Group in moving forward the agenda of innovative financing for development. I am indeed confident that the Seoul Meeting will contribute to making concrete advances in that regard.

Thank you 